Vol. 7 (1998): 513-521.

Research Note

\title{
Effects of restricted methionine and energy intake on egg weight and shell quality
}

Tuomo Kiiskinen

Agricultural Research Centre of Finland, Animal Production Research, FIN-31600 Jokioinen, Finland

Eija Helander

Suomen Rehu Oy, PO Box 105, FIN-00241 Helsinki, Finland

\begin{abstract}
An experiment involving two laying hen hybrids and four dietary treatments was conducted to study the effects of dietary methionine restriction (MR) $(3,05 \mathrm{~g} / \mathrm{kg}$, MR 100;2,65 g/kg, MR 87; 2,25 g/kg, MR 74) and energy restriction (ER) on egg production assessed as egg weight, egg weight classification and shell quality of eggs during the later laying phase from 46 to $70 \mathrm{wk}$ of age. Daily methionine intakes were 305 (MR 100), 273 (MR 87), 229 (MR 74) and 326 (ER) mg per bird. ER was 89\% of the calculated supply of MR100.

MR did not significantly affect hen-day production $(\%)$ but reduced linearly $(\mathrm{P}<0.001)$ egg weight. Average egg weights were 64.0 (MR 100), 63.1 (MR 87) and 60.6 g (MR 74). ER reduced egg weight to the same extent as MR 87 but its percentage laying was lower $(\mathrm{P}<0.05)$ than MR 87. Due to decreased egg weight feed conversion was considerably poorer for MR 74 than MR 100. Interactions between restriction and hybrid for egg production and feed intake, indicate differences in the requirements of methionine and energy between the two laying hybrids.

Significant differences in shell quality were only observed between hybrids. However, the results concerning shell defects and shell quality parameters (shell strength, specific gravity) indicated an improvement for MR 74.

In the classification of eggs MR increased linearly $(\mathrm{P}<0.001)$ the proportion of first class eggs, decreased the proportion of large (63-73 g) and extra large (>73 g) eggs, but increased medium (53-63 g) and small $(<53 \mathrm{~g})$ sized eggs. ER did not significantly affect the proportion of eggs in the quality classification, but did significantly $(\mathrm{P}<0.05)$ reduce the proportion of extra large eggs.

The results suggest that methionine restriction is an effective means for reducing egg weight which may also improve shell quality.
\end{abstract}

Key words: diet, egg shell quality, egg weight

\section{Introduction}

There are at least two reasons for controlling egg size during the second half of the laying period. For one thing large eggs cause reduced prices and for another we can expect that shell quality improves when egg size decreases. It has been indicated that the quantity of shell deposited on the egg either remains constant or increases slightly as the hen ages, although relative shell weight decreases (Roland et al. 1975, 1978, Ro-

\section{(C) Agricultural and Food Science in Finland} Manuscript received August 1998 
Kiiskinen, T. \& Helander, E. Effects of restricted methionine and energy intake on eggs

land 1979). This means that shell quality declines with hen age due to a continued increase in egg size and the constant amount of shell being spread as a thinner egg layer.

There are several nutritional factors which influence egg weight. Energy and protein restriction have been used for layers in order to avoid excessive intake which can lead to bird fatness and increased feeding costs. If the restriction has been severe enough, egg weight has decreased. Unfortunately the majority of the trials have started at the beginning of the laying period and there is a lack of information for production during the later laying phase. Auckland and Wilson (1975) found that energy restriction of about $92 \%$ from 56 to 68 weeks of age depressed the rate of lay by about 3 percentage units and egg weight by $1.1 \mathrm{~g}$. An earlier start of the restriction (32 wk) resulted in a marked depression of laying. Kiiskinen $(1974,1977)$ restricted layers' feed intake from 47-50 weeks of age for 5-6 months. A $92-98 \%$ restriction did not affect the rate of lay but did reduce egg weight by between 0.4 and $1.8 \mathrm{~g}$.

Methionine intake restriction has been studied to control egg weight and to improve shell quality (Petersen et al. 1983, Jackson et al. 1987). A low daily methionine supply of $255-263 \mathrm{mg}$ per bird did not markedly influence egg production (\%) when birds were older than 38-43 weeks of age. Egg weight was reduced by between 1.5$2.5 \mathrm{~g}$ and shell quality improved.

The aim of the present study was to examine the effects of methionine and energy restriction on egg production, egg weight, weight classification and shell quality in particular during the later laying phase.

\section{Material and methods}

\section{Birds and housing}

This study was conducted with 864 MÄ16 (Mäkelä) and 864 LSL (Lohmann White) hens and it started when the birds were 46 wk of age. Hens were kept in 2-tier batteries and housed three hens per cage $\left(640 \mathrm{~cm}^{2} / \mathrm{hen}\right)$. Temperature of $18 \pm 2^{\circ} \mathrm{C}$ and $15 \mathrm{~h}$ of light per day were maintained. Water was provided ad libitum from nipple drinkers.

\section{Experimental design}

The experiment which included 6 four weeks periods (46 to 70 weeks), had a 2 x 4 factorial design consisting of two hybrids and four dietary restrictions. Each dietary treatment group consisted of 24 replicates containing six adjacent cages (18 birds). Dietary treatments were randomly allocated between 4 successive replicates including the same hybrid.

\section{Experimental diets and feeding}

Four dietary treatments were used: (1) methionine $100 \%$ (MR 100); (2) methionine $87 \%$ (MR 87); (3) methionine 74\% (MR 74) and low energy diet (ER). Composition of experimental diets is shown in Table 1. The cool pelleted diets were formulated from soybean meal and cereals. Methionine restricted (MR) diets had a calculated metabolizable energy (AME) content of $10.7 \mathrm{MJ} / \mathrm{kg}$. AME content of the low energy (ER) diet was $9.8 \mathrm{MJ} / \mathrm{kg}$. The lower AME value of ER was achieved by omitting wheat and soybean oil. The ER diet was formulated to contain more protein, added minerals and vitamins than the other diets due to an intake restriction of around $115 \mathrm{~g} /$ hen/ day compared to $120 \mathrm{~g} / \mathrm{hen} /$ day for the methionine diets.

\section{Experimental procedures}

Eggs were collected and recorded daily for each replicate. Feed intake was measured on a replicate basis by weighing feed consumed during each 4 week period. Four replicates ( 2 MÄ16, 2 LSL) of hens fitted with a numbered foot ring 
Vol. 7 (1998): 513-521.

Table 1. Composition of experimental diets.

\begin{tabular}{|c|c|c|c|}
\hline & & $\begin{array}{l}\text { Methionine } \\
\text { diets } \\
\text { MR100/MR87/MR74 }\end{array}$ & $\begin{array}{l}\text { Low energy } \\
\text { diet (ER) }\end{array}$ \\
\hline \multicolumn{2}{|c|}{ Soybean meal g/kg } & 125 & 150.0 \\
\hline Barley & $"$ & 360 & 475.0 \\
\hline Oats & " & 240 & 260.0 \\
\hline Wheat & $"$ & 150 & - \\
\hline Soybean oil & " & 20 & - \\
\hline Limestone & $"$ & 86 & 90.0 \\
\hline $\begin{array}{l}\text { Dicalcium } \\
\text { phosphate }\end{array}$ & $"$ & 12 & 12.5 \\
\hline $\begin{array}{l}\text { Sodium } \\
\text { chloride }\end{array}$ & $"$ & 3 & 3.2 \\
\hline Premixes $^{1)}$ & $"$ & 4 & 4.3 \\
\hline $\begin{array}{l}\text { DL-methi- } \\
\text { onine } \\
\text { Calculated }\end{array}$ & $"$ & $0.8 / 0.4 /-$ & 0.9 \\
\hline Crude prote & / $/ \mathrm{kg}$ & 142 & 150 \\
\hline $\mathrm{Ca}$ & $"$ & 36.3 & 38.0 \\
\hline $\mathrm{P}$ available & $"$ & 3.0 & 3.1 \\
\hline $\mathrm{AME} \mathrm{MJ/k}$ & & 10.7 & 9.8 \\
\hline \multicolumn{4}{|c|}{ Methionine } \\
\hline \multicolumn{4}{|c|}{$\begin{array}{l}\text { Analysed content } \\
\text { (on a } 89 \% \text { DM basis) }\end{array}$} \\
\hline Crude prote & / $/ \mathrm{kg}$ & 137 & 144 \\
\hline Crude fat & $"$ & 46 & 29 \\
\hline Crude fibre & " & 57 & 70 \\
\hline Ash & $"$ & 92 & 92 \\
\hline
\end{tabular}

1) Added vitamins, trace elements and carotinoid pigments MR100 $=$ methionine $100 \%$, MR87 $=$ methionine $87 \%$, MR74 = methionine 74\%

$\mathrm{AME}=$ apparent metabolizable energy, $\mathrm{DM}=$ dry matter

per dietary treatment were weighed at the beginning and at the end of the trial. In the last weighing the condition of plumage in the neck, back, breast, wings and tail was also evaluated on a scale from 1 to $4(1=$ bare or nearly bare, $4=$ good or complete plumage). Thirty two eggs per treatment in the sixth period were collected from the same replicates used for egg quality determinations (shell strength, specific gravity, albumen height, proportions of egg components: albumen, yolk, shell). Specific gravity was measured by the Archimedes' method and a Wazan
Table 2. Dietary amino acid content (g/kg DM).

\begin{tabular}{lrrrr}
\hline Amino acid & MR100 & MR87 & MR74 & \multicolumn{1}{c}{ ER } \\
\hline Methionine & 2.86 & 2.55 & 2.16 & 3.15 \\
Cystine & 3.59 & 3.68 & 3.76 & 3.80 \\
Lysine & 6.22 & 6.50 & 6.39 & 7.77 \\
Arginine & 8.83 & 9.22 & 9.15 & 10.38 \\
Isoleucine & 5.42 & 5.66 & 5.55 & 6.22 \\
Leucine & 10.33 & 10.72 & 10.56 & 11.83 \\
Threonine & 5.08 & 5.24 & 5.17 & 5.90 \\
Histidine & 3.81 & 4.07 & 4.02 & 4.41 \\
Phenylalanine & 7.21 & 7.37 & 7.32 & 8.18 \\
Tyrosine & 4.98 & 5.15 & 5.20 & 5.84 \\
Valine & 7.03 & 7.24 & 7.08 & 7.92 \\
\hline
\end{tabular}

MR100 $=$ methionine $100 \%$, MR87 $=$ methionine $87 \%$, MR74 = methionine $74 \%$

$\mathrm{ER}=$ energy restriction, $\mathrm{DM}=$ dry matter

compression force meter was used for the determination of shell strength. Albumen height was evaluated by Ames HU micrometer (Haugh Unit). The number of broken, cracked and shelless eggs for one day production were checked once per period during the last 5 periods. Egg quality and egg weight classification data was obtained from the egg packing company.

\section{Chemical analysis and statistics}

The proximate analysis was performed using standard procedures (AOAC 1984) for each batch of experimental diets. Measured crude protein contents of the diets were about $5 \mathrm{~g} / \mathrm{kg}$ lower than calculated values (Table 1$)$. Amino acids were hydrolysed $\left(6 \mathrm{~N} \mathrm{HCI}, 110^{\circ} \mathrm{C}, 23 \mathrm{~h}\right)$ prior to analysis. Before hydrolysis methionine and cystine were oxidised using performic acid. Amino acids were analysed with a Beckman 6300 amino acid analyser.

Determined methionine and lysine contents (Table 2) were lower than calculated values partly due to the lower protein content (Table 1). Calculating values based on a $89 \%$ dry matter content, methionine concentrations were $2.55 \mathrm{~g} /$ kg (MR100), 2.27 g/ kg (MR87), 1.92 g/ kg (MR74) and $2.80 \mathrm{~g} / \mathrm{kg}$ (ER). Corresponding 
Kiiskinen, T. \& Helander, E. Effects of restricted methionine and energy intake on eggs

mean lysine contents of the MR diets was 5.67 $\mathrm{g} / \mathrm{kg}$ and that for the ER diet $6.92 \mathrm{~g} / \mathrm{kg}$.

Performance and egg quality data were subjected to the analysis of variance using the GLM procedure of SAS (SAS 1988). The model included the effects of restriction and breed and their interaction (Snedecor and Cochran 1989). Six cages of three hens (total 18 hens) formed an experimental unit. Residuals were checked for normality and plotted against fitted values by using the UNIVARIATE and PLOT procedures of SAS. Comparisons between treatment means were made using Tukey test. Frequencies of rejected eggs (total) were analysed with the CATMOD procedure of SAS having effects of restriction and breed and their interaction in the model. Treatments with methionine or energy restriction (MR 87, MR 74 or ER) were compared to the unrestricted treatment (MR 100) using the CONTRAST statement.

\section{Results and discussion}

\section{Egg production and egg weight}

In general, hen-day production $77-80 \%$ was similar for each dietary treatment excluding LSL hens fed the ER diet (Table 3). Methionine restriction did not significantly affect laying of either hybrid. Based on daily feed intake (Table 3 ) and measured methionine content (Table 2), daily methionine supplies per bird were $305 \mathrm{mg}$ (MR 100), 273 mg (MR 87), 229 mg (MR 74) and $326 \mathrm{mg}$ (ER). In the study of Petersen et al. (1983) methionine supply varied from 255 to 300 $\mathrm{mg} /$ hen / day and they did not observe significant differences in hen-day production between 38 and 102 weeks of age. Jackson et al. (1987) used dietary methionine contents of $0.233-$ $0.383 \%$, which corresponded to a daily intake of 268-448 mg. These authors demonstrated a reduction of production at early ages (30 and 43 wk) but not later. It seems that a marked methionine restriction up to $230 \mathrm{mg} /$ hen / day does not affect percentage laying if the restriction begins at the age of 45 weeks. This is considerably less than the NRC (1994) recommendation of $300 \mathrm{mg} / \mathrm{hen} / \mathrm{day}$, for optimal production ( $\mathrm{g} /$ hen / day) and feed efficiency.

ER reduced considerably laying of the LSL hens and a significant $(\mathrm{P}<0.05)$ interaction between restriction and hybrid $(\mathrm{R} \times \mathrm{H})$ was observed for hen-day production. Obviously LSL has a higher energy requirement than MÄ16 and therefore energy supply was insufficient for LSL fed diet ER. Metabolizable energy (ME) requirements of a caged hen in this production phase is 1.20-1.25 MJ / day (Salo et al. 1982). According to tables 1 and 3 calculated ME intake was 1.14 MJ / day among the ER hens and 1.28 MJ / day among the MR 100 hens. So the energy restriction was $89 \%$.

In this trial MÄ16 produced more $(\mathrm{P}<0.05)$ eggs than LSL. In the earlier comparisons LSL has layed either higher (Kiiskinen and Huida 1990, Pärko and Stolt 1993, Suomen Siipikarja 1996) or equal number of eggs than MÄ16 (Kiiskinen 1996), during the entire production period.

MR reduced linearly $(\mathrm{P}<0.001)$ egg weight. The average reduction was 0.9 and $3.4 \mathrm{~g}$ for MR87 and MR74, respectively. Petersen et al. (1983) reported a reduction of 1.6-2.3 $\mathrm{g}$ in egg weight, during a methionine restriction of $85 \%$. In the study of Jackson et al. (1987) a maximum reduction of 4-4.5 g was obtained when methionine restriction was around $70 \%$. Although ER in the present study was rather severe, its effect on egg weight was less marked than that of MR. On average ER reduced egg weight by $0.7 \mathrm{~g}$. During this laying phase hybrids produced eggs of the same average weight.

\section{Feed intake and feed efficiency}

Hens consumed approximately all offered feed (Table 3). The MÄ16 hens, which were fed the MR74 diet, ate less $(\mathrm{P}<0.05)$ than comparable hybrids fed MR diets. Apparently the methionine content of MR74 was insufficient for MÄ16 and caused a reduction in feed intake. This implies a difference in methionine requirement 
Vol. 7 (1998): 513-521.

Table 3. Effect of dietary treatment and laying hen hybrid on egg production and feed intake.

\begin{tabular}{|c|c|c|c|c|c|}
\hline & $\begin{array}{l}\text { Egg } \\
\text { laying } \\
\% \\
\end{array}$ & $\begin{array}{l}\text { Egg } \\
\text { weight } \\
\text { g }\end{array}$ & $\begin{array}{l}\text { Egg } \\
\text { prod. } \\
\text { g/h/d }\end{array}$ & $\begin{array}{l}\text { Feed } \\
\text { intake } \\
\mathrm{g} / \mathrm{h} / \mathrm{d}\end{array}$ & $\begin{array}{l}\text { FCR } \\
\mathrm{kg} / \mathrm{kg}\end{array}$ \\
\hline \multicolumn{6}{|l|}{ MÄ16 } \\
\hline MR100 & 80.0 & 64.2 & $51.4^{\mathrm{B}}$ & $119.5^{\mathrm{B}}$ & $2.33^{\mathrm{A}}$ \\
\hline MR87 & 79.0 & 63.4 & $50.0^{\mathrm{B}}$ & $119.5^{\mathrm{B}}$ & $2.40^{\mathrm{AB}}$ \\
\hline MR74 & 77.8 & 60.5 & $47.0^{\mathrm{A}}$ & $117.5^{\mathrm{A}}$ & $2.51^{\mathrm{B}}$ \\
\hline ER & 78.2 & 63.2 & $49.4^{\mathrm{AB}}$ & $116.2^{\mathrm{A}}$ & $2.36^{\mathrm{A}}$ \\
\hline Mean & 78.8 & 62.8 & 49.4 & 118.2 & 2.40 \\
\hline \multicolumn{6}{|l|}{ LSL } \\
\hline MR100 & $77.1^{\mathrm{ab}}$ & $63.8^{b}$ & $49.1^{b}$ & $119.7^{\mathrm{b}}$ & $2.46^{\mathrm{ab}}$ \\
\hline MR87 & $79.5^{\mathrm{b}}$ & $62.8^{b}$ & $49.8^{\mathrm{b}}$ & $119.9^{b}$ & $2.42^{\mathrm{a}}$ \\
\hline MR74 & $77.8^{\mathrm{ab}}$ & $60.7^{\mathrm{a}}$ & $47.1^{\mathrm{ab}}$ & $119.9^{b}$ & $2.57^{\mathrm{b}}$ \\
\hline ER & $73.4^{\mathrm{a}}$ & $63.3^{\mathrm{b}}$ & $46.4^{\mathrm{a}}$ & $116.4^{\mathrm{a}}$ & $2.53^{\mathrm{ab}}$ \\
\hline Mean & 76.9 & 62.7 & 48.1 & 119.0 & 2.49 \\
\hline SEM & 1.04 & 0.23 & 0.61 & 0.34 & 0.034 \\
\hline \multicolumn{6}{|l|}{ Significance } \\
\hline Restriction (R) & $* *$ & $* * *$ & $* * *$ & $* * *$ & $* * *$ \\
\hline Hybrid $(\mathrm{H})$ & $*$ & NS & $* *$ & $* *$ & $* * *$ \\
\hline $\mathrm{R} \times \mathrm{H}$ & $*$ & NS & $*$ & $* *$ & NS \\
\hline MR linear & NS & $* * *$ & $* * *$ & - & - \\
\hline
\end{tabular}

A-B, a-b Means in the same column with a different superscript letter are significantly $(\mathrm{P}<0.05)$ different.

Significances: NS $=$ non-significant, $*=\mathrm{P}<0.05, * *=\mathrm{P}<0.01, * * *=\mathrm{P}<0.001$

MR100 = methionine $100 \%$, MR87 = methionine $87 \%$, MR74 = methionine $74 \%$, ER = energy restriction

$\mathrm{SEM}=$ standard error of mean

$\mathrm{R} \times \mathrm{H}=$ interaction between restriction and hybrid

$\mathrm{FCR}=$ feed conversion ratio

between hybrids. The ER hens ate a little bit more than the restricted ration $115 \mathrm{~g} / \mathrm{day}$. This was possible if birds died during the period for which feed was weighed into the small containers of the feed chain. As a result of decreased egg weight and production, MR74 had a higher feed conversion ratio (FCR) and this effect was significant $(\mathrm{P}<0.05)$ among M $\mathrm{A} 16$ hens. Also ER increased FCR of both hybrids, but differences compared with MR 100 were not significant. In this laying phase MÄ16 utilized feed more efficiently $(\mathrm{P}<0.001)$ than LSL.

\section{Mortality, body weight and plumage}

Mortality varied between 2.1 and $3.5 \%$ and was not greatly influenced by the choice of die- tary restriction. Corresponding restriction methods have not been reported to increase mortality (Petersen et al. 1983, Jackson et al. 1987, Auckland and Wilson 1975, Kiiskinen 1974, 1977). There were significant $(\mathrm{P}<0.01)$ differences in body weight between dietary treatments at the end of the trial (Table 4). MR decreased the final weight linearly $(\mathrm{P}<0.001)$ and also ER reduced weight $(\mathrm{P}<0.05)$ compared to MR100. Only MR100 hens increased their weight during the trial. Also Petersen et al. (1983) noted a reduced weight gain in methionine restricted hens. The MÄ16 hens were heavier $(\mathrm{P}<0.001)$ than LSL hens both at the beginning and at the end of the trial. This distinction has been also observed in the earlier reports (Kiiskinen and Huida 1990, Pärko and Stolt 1993, Suomen Siipikarja 1996). Reduction of body weight of LSL refers that the 
Kiiskinen, T. \& Helander, E. Effects of restricted methionine and energy intake on eggs

Table 4. Effect of dietary treatment and laying hen hybrid on body weight and feather score.

\begin{tabular}{llll}
\hline & \multicolumn{2}{l}{ Body weight kg } & Feather \\
& $46 \mathrm{wk}$ & $70 \mathrm{wk}$ & score total \\
\hline Restriction (R) & & & \\
MR100 & 1.84 & $1.90^{\mathrm{c}}$ & 12.1 \\
MR87 & 1.84 & $1.84^{\mathrm{bc}}$ & 11.7 \\
MR74 & 1.82 & $1.74^{\mathrm{a}}$ & 12.2 \\
ER & 1.84 & $1.77^{\mathrm{ab}}$ & 13.1 \\
SEM & 0.015 & 0.022 & 1.38 \\
Hybrid (H) & & & \\
MÄ16 & 1.88 & 1.90 & 12.2 \\
LSL & 1.78 & 1.72 & 12.3 \\
SEM & 0.011 & 0.016 & 0.98 \\
Significance & & & \\
R & NS & $* * *$ & NS \\
H & $* * *$ & $* * *$ & NS \\
R x H & NS & NS & NS \\
MR linear & NS & $* * *$ & NS \\
\hline
\end{tabular}

a-c Means in the same column with a different superscript letter are significantly $(\mathrm{P}<0.05)$ different.

Significances: NS = non-significant, $0=\mathrm{P}<0.1$, ** $=\mathrm{P}<0.01$, $* * *=\mathrm{P}<0.001$

MR100 = methionine $100 \%$, MR87 = methionine $87 \%$, MR74 = methionine 74\%, ER = energy restriction $\mathrm{SEM}=$ standard error of mean

$\mathrm{R} \times \mathrm{H}=$ interaction between restriction and hybrid $\mathrm{FCR}=$ feed conversion ratio

daily allowance of feed was insufficient for this hen hybrid. Dietary restriction had no significant effect on feather cover (Table 4).

\section{Egg quality and egg components}

Eggs laid by the MR74 hens contained significantly $(\mathrm{P}<0.05)$ less shell defects than eggs of the MR100 hens (Table 5). Shell strength and specific gravity of MR74 and ER were non-significantly higher than MR100 (Table 6). Petersen et al. (1983) and Jackson et al. (1987) found for the greatest methionine restriction in particular improved egg shell quality and their results support those of the present study. Shell and egg white quality (Haugh) of LSL eggs were significantly $(\mathrm{P}<0.001)$ better than those of MÄ16 eggs. ER increased $(\mathrm{P}<0.05)$ the proportion of egg white and decreased that of yolk and shell. MR did not significantly affect the proportions of each egg component. Shafer et al. (1996) fed higher methionine levels and found that methionine intake did not influence the relative yield of albumen and yolk but did increase the crude protein content of these components. Eggs of LSL contained more egg white, less yolk $(\mathrm{P}<0.05)$ and more shell $(\mathrm{P}<0.05)$ than eggs of $\mathrm{MÄ16}$. These results concerning differences in the proportion of albumen and yolk between hybrids are consistent with earlier observations (Kiiskinen and Huida 1990).

\section{Quality and weight classifications of eggs}

Methionine restriction increased linearly $(\mathrm{P}<0.001)$ the proportion of first class eggs and

Table 5. Effect of dietary treatment and laying hen hybrid on the incidence of egg shell defects.

\begin{tabular}{llllllll}
\hline & \multicolumn{4}{c}{ Restriction } & & \multicolumn{2}{c}{ Hybrid } \\
\cline { 2 - 4 } \cline { 7 - 8 } & MR100 & MR87 & MR74 & ER & & MÄ16 & LSL \\
\hline Broken \% & 5.1 & 5.7 & 3.7 & 4.4 & & 4.7 & 4.8 \\
Cracked " & 7.4 & 8.6 & 5.9 & 6.9 & & 7.6 & 6.8 \\
Shelless " & 2.8 & 2.5 & 1.1 & 2.3 & & 2.9 & 1.4 \\
Other " & 0.03 & 1.3 & 0.7 & 2.0 & & 0.4 & 1.6 \\
Total ${ }^{1)} "$ & 15.4 & 18.2 & 11.5 & 15.5 & & 15.7 & 14.6 \\
\hline
\end{tabular}

${ }^{1)}$ MR74 differed significantly from MR100 ( $\left.<<0.05\right)$. 
Vol. 7 (1998): 513-521.

Table 6. Effect of dietary treatment and laying hen hybrid on mean egg quality traits measured in the poultry house.

\begin{tabular}{|c|c|c|c|c|c|c|c|c|c|c|c|}
\hline & \multicolumn{4}{|c|}{ Restriction (R) } & \multirow[t]{2}{*}{ SEM } & \multicolumn{2}{|c|}{ Hybrid $(\mathrm{H})$} & \multirow[t]{2}{*}{ SEM } & \multicolumn{3}{|c|}{ Significance } \\
\hline & MR100 & MR87 & MR74 & ER & & MÄ16 & LSL & & $\mathrm{R}$ & $\mathrm{H}$ & $\mathrm{R} \times \mathrm{H}$ \\
\hline Shell strength(N) & 28.7 & 27.5 & 30.2 & 29.6 & 0.70 & 26.9 & 31.2 & 0.49 & NS & $* * *$ & NS \\
\hline Spec. gravity & .0814 & .0818 & .0821 & .0832 & .00067 & .0790 & .0853 & .00047 & NS & $* * *$ & NS \\
\hline Haugh & 79.5 & 80.6 & 80.2 & 81.2 & 0.88 & 78.9 & 81.8 & 0.62 & NS & $* *$ & NS \\
\hline Egg components \% & & & & & & & & & & & \\
\hline white & $60.6^{\mathrm{a}}$ & $61.1^{\mathrm{ab}}$ & $60.3^{\mathrm{a}}$ & $61.9^{\mathrm{b}}$ & 0.31 & 60.8 & 61.2 & 0.22 & **** & NS & NS \\
\hline yolk & 29.0 & 28.6 & 29.1 & 28.2 & 0.29 & 29.1 & 28.3 & 0.20 & NS & * & NS \\
\hline shell & 10.2 & 10.1 & 10.1 & 9.7 & 0.14 & 9.8 & 10.2 & 0.10 & NS & * & NS \\
\hline
\end{tabular}

$\mathrm{a}-\mathrm{b}$ Means in the same row with a different superscript letter are significantly $(\mathrm{P}<0.05)$ different.

Significances: NS $=$ non-significant, $*=\mathrm{P}<0.05, * *=\mathrm{P}<0.01, * * *=\mathrm{P}<0.001$

MR100 = methionine $100 \%$, MR87 = methionine $87 \%$, MR74 = methionine $74 \%$, ER = energy restriction

$\mathrm{SEM}=$ standard error of mean

$\mathrm{R} \times \mathrm{H}=$ interaction between restriction and hybrid

$\mathrm{FCR}=$ feed conversion ratio

$\mathrm{N}=$ newton

decreased $(\mathrm{P}<0.001)$ that of second class and unqualified eggs (Table 7). Effects of energy restriction were not significant. MR decreased linearly $(\mathrm{P}<0.001)$ the proportion of large $(63-$ $73 \mathrm{~g})$ and extra large (>73 g) eggs and increased $(\mathrm{P}<0.001)$ those of medium $(53-63 \mathrm{~g})$ and small $(<53 \mathrm{~g})$ eggs (Table 7). ER reduced significant- ly $(\mathrm{P}<0.05)$ extra large eggs, but did not influence the proportion of eggs classified in other weight classes.

Using a maximum price of 1.40 Fmk per kilo feed and price differences in the quality and weight classes of eggs and account for the cost of methionine, restriction of this amino acid can

Table 7. Effect of dietary treatment on the classification and distribution of eggs to the different weight classes, measured by the egg packing company.

\begin{tabular}{|c|c|c|c|c|c|c|c|}
\hline & \multirow{2}{*}{$\begin{array}{l}\text { 1st class } \\
\%\end{array}$} & \multirow{2}{*}{$\begin{array}{l}\text { 2nd class } \\
\%\end{array}$} & \multirow{2}{*}{$\begin{array}{l}\text { Unqua- } \\
\text { lified } \\
\%\end{array}$} & \multicolumn{4}{|c|}{ Weight distribution of the 1 st class eggs } \\
\hline & & & & $<53 \mathrm{~g}$ & $53-63 g$ & $63-73 g$ & $>73 \mathrm{~g}$ \\
\hline \multicolumn{8}{|c|}{ Restriction (R) } \\
\hline MR100 & $78.8^{\mathrm{a}}$ & $17.1^{\mathrm{b}}$ & $4.2^{\mathrm{b}}$ & $0.1^{\mathrm{a}}$ & $18.9^{\mathrm{a}}$ & $69.6^{b}$ & $11.4^{\mathrm{c}}$ \\
\hline MR87 & $80.2^{\mathrm{a}}$ & $16.0^{\mathrm{b}}$ & $3.7^{\mathrm{ab}}$ & $0.1^{\mathrm{a}}$ & $24.7^{\mathrm{b}}$ & $67.5^{b}$ & $7.7^{\mathrm{b}}$ \\
\hline MR74 & $82.9^{b}$ & $14.1^{\mathrm{a}}$ & $3.0^{\mathrm{a}}$ & $1.0^{\mathrm{b}}$ & $44.9^{\mathrm{c}}$ & $50.8^{\mathrm{a}}$ & $3.3^{\mathrm{a}}$ \\
\hline ER & $79.9^{\mathrm{a}}$ & $16.3^{\mathrm{b}}$ & $3.9^{\mathrm{b}}$ & $0.2^{\mathrm{a}}$ & $22.5^{\mathrm{ab}}$ & $68.5^{\mathrm{b}}$ & $8.8^{b}$ \\
\hline SEM & 0.56 & 0.42 & 0.20 & 0.05 & 0.93 & 0.60 & 0.49 \\
\hline \multicolumn{8}{|c|}{ Significance } \\
\hline $\mathrm{R}$ & $* * *$ & $* * *$ & $* * *$ & $* * *$ & $* * *$ & $* * *$ & $* * *$ \\
\hline MR linear & $* * *$ & $* * *$ & $* * *$ & $* * *$ & $* * *$ & $* * *$ & $* * *$ \\
\hline
\end{tabular}

a-c Means in the same column with a different superscript letter are significantly $(\mathrm{P}<0.05)$ different.

Significances: NS = non-significant, $* * *=\mathrm{P}<0.001$

MR100 = methionine $100 \%$, MR87 = methionine $87 \%$, MR74 $=$ methionine $74 \%$

$\mathrm{SEM}=$ standard error of mean 


\section{AGRICULTURAL AND FOOD SCIENCE IN FINLAND}

Kiiskinen, T. \& Helander, E. Effects of restricted methionine and energy intake on eggs

produce a profit of around 10 pennies per kilogram of eggs.

\section{Conclusions}

Restriction of methionine intake (74\%) during the later phase of the laying period proved to be an effective means to decrease egg weight. It did not affect laying intensity and appeared to improve egg shell quality. A relatively severe energy restriction (89\%) was not as effective in decreasing egg weight and seemed to reduce laying percentage.

Acknowledgements. This study was financially supported by Suomen Rehu Oy for which the authors present their warmest appreciation.

\section{References}

AOAC 1984. Official methods of analysis. 14th edition. Association of Official Analytical Chemist. Arlington, Virginia. $1141 \mathrm{p}$.

Auckland, J.N. \& Wilson, S.B. 1975. Effects of moderate energy restriction on light and medium hybrid laying hens. British Poultry Science 16: 23-29.

Jackson, M.E., Hellwig, H.M. \& Waldroup, P.W. 1987. Shell quality: potential for improvement by dietary means and relationship with egg size. Poultry Science 66: 1702-1713.

Kiiskinen, T. 1974. Rajoitettu ruokinta muniville kanoille. Siipikarja 56: 170-175.

- 1977. Rehun rajoitus munintakauden lopulla kannattaisi meilläkin. Siipikarja 59: 7-8.

- 1996. Tilasekoituksien vaikutukset munantuotantoon. Suomen Siipikarja 78: 24-26.

- \& Huida, L. 1990. Effects of two feeding regimens on production and egg quality of six laying hen hybrids. Annales Agriculturae Fenniae 29: 113-126.

NRC 1994. Nutrient requirements of poultry. Ninth revised edition. National Research Council. Washington DC. $155 \mathrm{p}$.

Petersen, C.F., Sauter, E.A., Steele, E.E. \& Parkinson, J.F. 1983. Use of methionine intake restriction to improve egg shell quality by control of egg weight. Poultry Science 62: 2044-2047.
Pärkö, J. \& Stolt, J. 1993. Humppilan kanatalousaseman tulokset 1992-1993. Siipikarja 75: 190-191, 193.

Roland, D.A. Sr. 1979. Factors influencing shell quality of ageing hens. Poultry Science 58: 774-777.

-, Sloan, D.R. \& Harms, R.H. 1975. The ability of hens to maintain calcium deposition in the egg shell and egg yolk as the hen ages. Poultry Science 54: 17201723.

-, Putnam, C.E. \& Hilburn, R.L. 1978. The influence of age on ability of hens to maintain egg shell calcification when stressed with inadequate dietary calcium. Poultry Science 57: 1616-1621.

Salo, M-L., Tuori, M. \& Kiiskinen, T. 1982. Rehutaulukot ja ruokintanormit. 70 p. Helsinki.

SAS 1988. SAS/STAT User's Guide (Version 6, 4th Ed.). SAS Institute Inc., Cary, NC. 1686 p.

Shafer, D.J., Carey, J.B. \& Prochaska, J.F. 1996. Effect of dietary methionine intake on egg component yield and composition. Poultry Science 75: 1080-1085.

Snedecor, G.W. \& Cochran, W.G. 1989. Statistical Methods ( $8^{\text {th }} \mathrm{Ed}$.), lowa State University Press, Ames. 503 p.

Suomen Siipikarja 1996. Humppilan koeasema. Hybridivertailukokeen tulokset 1995-1996. Nr 2 p. 9, 1213. 
Vol. 7 (1998): 513-521.

\title{
SELOSTUS
}

\section{Metioniinin ja energian saannin rajoittamisen vaikutukset kananmunan painoon ja laatuun}

\author{
Tuomo Kiiskinen ja Eija Helander \\ Maatalouden Tutkimuskeskus ja Suomen Rehu Oy
}

Ylisuuret kananmunat alentavat tuottajahintaa. Metioniiniaminohapon ja energian saannin rajoittamisen vaikutusta selvitettiin munantuotannon, erityisesti munan painon ja kuoren laadun kannalta. Metioniinipitoisuuden rajoitus rehussa oli 87 ja 74\% vertailutasoon nähden. Rehua annettiin kaikille metioniiniryhmille enintään $120 \mathrm{~g} / \mathrm{kana} /$ päivä. Energiarajoituksessa rehun muuntokelpoisen energian pitoisuus oli $91.5 \%$ vertailuryhmän pitoisuudesta ja kun rehuannos rajoitettiin $115 \mathrm{~g}$ :aan päivässä, oli energiarajoitus kokonaisuudessaan $89 \%$. Koe suoritettiin ikävälillä 46-70 vk ja siinä käytettiin kahta kanahybridiä (MÄ16, LSL).

Metioniinin rajoitus ei vaikuttanut merkitsevästi kanojen munintaan, mutta pienensi lineaarisesti munan painoa. Munan keskipainot olivat 64.0 (100\%),
$63.1(87 \%)$ ja 60.6 g (74\%). Energiarajoitus alensi munan painoa yhtä tehokkaasti kuin $87 \%$ :n metioniinirajoitus, mutta muninta jäi LSL-kanalla merkitsevästi heikommaksi. Voimakas munan painon lasku aiheutti 74\%:n metioniinirajoituksella huomattavan rehuhyötysuhteen suurenemisen. Tulokset viittaavat metioniinin ja energian tarpeen eroihin hybridien välillä.

Kuoren laatua koskevissa tuloksissa oli havaittavissa sen parantumista runsaalla metioniinin ja energian rajoittamisella. Munan laatuluokituksessa metioniinirajoitus lisäsi merkitsevästi ykkösluokan munia ja vähensi suurten (63-73 g) ja ylisuurten (>73 g) munien osuutta. Energiarajoitus ei vaikuttanut merkitsevästi laatuluokitukseen, mutta vähensi merkitsevästi ylisuurten munien määrää. 
AGRICULTURAL AND FOOD SCIENCE IN FINLAND

522 